усложнения конструкции диспозиции части 1 статьи 14.1 Кодекса, не влекущего за собой (в текущей редакции) никаких правовых последствий. Отметим, что эта неточность, носит устранимый характер, а это позволяет надеяться, на её исключение в дельнейшем.

$$
* * *
$$

1. Кодекс Российской Федерации об административных правонарушениях. Главы 11 - 18. Постатейный научно-практический комментарий / И. А. Аксенов и др.; под общ.ред. Б. В. Россинского. Доступ из СПС «Консультант Плюс».

2. Комментарий к Кодексу Российской Федерации об административных правонарушениях (постатейный) / А. Г. Авдейко, С. Н. Антонов, И. Л. Бачило и др.; под общ.ред. Н. Г. Салищевой. 7-е изд. Доступ из СПС «Консультант Плюс».

3. Постановление Пленума Верховного Суда РФ от 24 октября 2006 г. № 18 «О некоторых вопросах, возникающих у судов при применении Особенной части Кодекса Российской Федерации об административных правонарушениях». Доступ из СПС «Консультант Плюс».

4. Пояснительная записка к проекту федерального закона «О внесении изменений в Кодекс Российской Федерации об административных правонарушениях» (в части усиления ответственности за незаконную продажу алкогольной продукции). URL: http://sozd.parlament.gov.ru/bill/994938-6 (дата обращения: 24.02.2018).

5. Федеральный закон от 29 июля 2017 г. № 265-Ф3 «О внесении изменений в Кодекс Российской Федерации об административных правонарушениях в части усиления ответственности за незаконную продажу алкогольной продукции». Доступ из СПС «КонсультантПлюс».

\title{
Румянцев C.A. \\ Применение института самозащиты при исполнении сотрудниками полиции служебных обязанностей
}

Юридический институт Владимирского государственного университета (Россия, Владимир)

doi:10.18411/lj-31-03-2018-68

idsp: 000001:lj-31-03-2018-68

\section{Аннотация}

В статье автор рассматривает различные аспекты реализации сотрудником полиции права на самозащиту при выполнении служебной деятельности. Автор приходит к выводу, что пределы реализации права сотрудника полиции на самозащиту связаны не с содержанием субъективного права на самозащиту, а с особым порядком его реализации.

Ключевые слова: самозащита, полиция, субъективное право, осуществление права, способы защиты прав, формы защиты.

\section{Abstract}

In the article the author considers various aspects of the implementation by a police officer the right to self-defense while execution their official activities. The author comes to the conclusion that the limits of realization of the right of a police officer in self-defense are not related to the content of the subjective right to self-defense, but with a special order of its implementation.

Key words: self-defense, the police, subjective right, the exercise of the rights, remedies, and forms of protection.

В настоящее время в нашей стране поддерживается развитие потенциала самореализации и гражданской инициативы во многих сферах [1], в том числе в сфере самостоятельной защиты своих прав.

Право на самозащиту, являясь естественным правом человека, закреплено в Конституции Российской Федерации, часть 2 статьи 45 которой предусматривает, что каждый вправе защищать свои права и свободы всеми способами, не запрещенными законом. 
Действия граждан, юридических лиц, публично-правовых образований по самостоятельной защите своих прав любыми способами, которые не запрещены законом, охватываются понятием «самозащита».

Самозащита как форма защиты прав имеет ряд преимуществ по сравнению с другими формами защиты: экономичность, оперативность, отсутствие необходимости обращаться в органы власти для защиты права, отсутствие срока давности, неотвратимость, эффективность и др.

Характер и степень нормативного правового обеспечения реализации права на самозащиту являются одними из ключевых характеристик уровня развития демократии в стране, поскольку, с одной стороны, самозащита позволяет, минуя государственные и иные юрисдикционные органы, защищать свои права и законные интересы, а с другой только при наличии детализированных нормативных критериев возможности реализации права на самозащиту, ее пределов, правовых последствий превышения пределов, самозащита не превратится в самоуправство.

Сотрудники полиции, выполняя задачи по защите жизни, здоровья, прав и свобод людей, по противодействию преступности, охране общественного порядка и собственности, обеспечению общественной безопасности, т.е. реализуя функции от имени государства в рамках юрисдикционной формы защиты, могут сами испытывать нарушение своих прав вследствие различных посягательств и защищать свои права самостоятельно, реализуя потенциал самозащиты.

Что касается физической самозащиты, то особый статус, физическая подготовка, возможность использования спецсредств, информированность, использование оперативных данных и другие «преимущества» сотрудника полиции предполагают наличие специальных правил при реализации им права на самооборону.

Проведенные исследования [2] показывают, что наиболее часто при отражении нападений на сотрудников полиции или при оказании помощи гражданам, на которых совершали нападение правонарушители, сотрудниками полиции применяются боевые приемы борьбы. При контактном взаимодействии сотрудники полиции наиболее часто использовали удары (более 50\%) и различные приемы борьбы (более 30\%). Из видов защит сотрудниками полиции наиболее часто используются уходы (около 40\%), уклоны (около 30\%), отбивы (около 15\%), подставки (около 15\%). Безусловно, максимально успешно боевые приемы применяются сотрудниками, имеющими навыки занятий спортивными единоборствами (самбо, дзюдо, бокс, кикбоксинг, карате и др.). Действия сотрудника полиции, как правило, состоят из следующего алгоритма действий: отвлекающее движение с ударом рукой или ногой в уязвимые места; выбивание оружия (если преступник вооружен) с дальнейшим выполнением броска; удержание с удушением или болевой прием; переход на прием контроля.

Применение физической силы, специальных средств и огнестрельного оружия сотрудником полиции регламентированы главой 5 Федерального закона от 7 февраля 2011 г. № 3-Ф3 «О полиции» [3].

В соответствии с пунктом 3 статьи 18 указанного Федерального закона сотрудник полиции в состоянии необходимой обороны, а также в случае крайней необходимости или при задержании лица, совершившего преступление, при отсутствии необходимых специальных средств или огнестрельного оружия вправе использовать любые подручные средства, а также применять не состоящее на вооружении полиции оружие.

В данном случае, как справедливо отмечается в литературе, право на причинение вреда сотрудником полиции не ограничено дополнительными требованиями профессионального характера [4].

Пунктом 8 статьи 18 Федерального закона от 7 февраля 2011 г. № 3-Ф3 «О полиции» предусмотрено, что превышение сотрудником полиции полномочий при применении физической силы, специальных средств или огнестрельного оружия влечет ответственность, установленную законодательством Российской Федерации. 
Указанная норма соотносится с положениями части 3 статьи 37 Уголовного кодекса Российской Федерации (далее также - УК РФ), согласно которой положения статьи 37 УК РФ о необходимой обороне в равной мере распространяются на всех лиц независимо от их профессиональной или иной специальной подготовки и служебного положения.

Приведем пример. Приговором Приморского краевого суда от 8 мая 2007 г. Г. был оправдан по обвинению в убийстве двух лиц - И. и К., совершенном на почве личных неприязненных отношений в ходе возникшей ссоры и драки ночью в помещении подъезда дома за отсутствием состава преступления. На указанный приговор государственным обвинителем было подано кассационное представление, в котором указано, что выводы суда о необходимой обороне 3. являются необоснованными. Оставляя кассационное представление без удовлетворения, а приговор Приморского краевого суда без изменения, Судебная коллегия по уголовным делам Верховного Суда Российской Федерации указала, что ссылки государственного обвинителя, содержащиеся в кассационном представлении, на боевую подготовку 3. и его физические данные прямо противоречат положениям части 3 статьи 37 УК РФ, согласно которой право на необходимую оборону имеют в равной мере все лица независимо от их профессиональной или иной подготовки [5].

Согласно части 9 Федерального закона от 7 февраля 2011 г. № 3-Ф3 «О полиции» сотрудник полиции освобождается от ответственности за вред, причиненный гражданам и организациям при применении физической силы, специальных средств или огнестрельного оружия, если их применение осуществлялось по основаниям и в порядке, установленными законом.

Применение указанной нормы, устанавливающей, в том числе, обстоятельство, исключающее преступность деяния, затруднительно, поскольку аналогичная норма отсутствует в УК РФ.

Статья 19 Федерального закона от 7 февраля 2011 г. № 3-Ф3 «О полиции» регламентирует порядок применения сотрудником полиции физической силы, специальных средств или огнестрельного оружия.

Так, сотрудник полиции сначала обязан сообщить лицам, в отношении которых предполагается применение физической силы, специальных средств или огнестрельного оружия, о том, что он является сотрудником полиции, предупредить их о своем намерении и в обязательном порядке - предоставить им возможность и время для выполнения законных требований сотрудника полиции.

Только если промедление в применении физической силы, специальных средств или огнестрельного оружия создает непосредственную угрозу жизни и здоровью гражданина или сотрудника полиции либо может повлечь иные тяжкие последствия, сотрудник полиции вправе не предупреждать о своем намерении.

Кроме того, сотрудник полиции при применении физической силы, специальных средств или огнестрельного оружия должен действовать с учетом создавшейся обстановки, характера и степени опасности действий лиц, в отношении которых применяются указанные средства, характера и силы оказываемого ими сопротивления. Сотрудник полиции обязан при этом стремиться к минимизации любого возможного ущерба.

Статьей 20 Федерального закона от 7 февраля 2011 г. № 3-Ф3 «О полиции» установлено, что сотрудник полиции имеет право применять физическую силу, в том числе боевые приемы борьбы, если несиловые способы не обеспечивают выполнения возложенных на полицию обязанностей, в следующих случаях: для пресечения преступлений и административных правонарушений; для доставления в служебное помещение полиции или в иное служебное помещение лиц, совершивших преступления и административные правонарушения, и задержания этих лиц; для преодоления 
противодействия законным требованиям сотрудника полиции. Сотрудник полиции имеет право применять физическую силу во всех случаях, когда законом разрешено применение специальных средств или огнестрельного оружия.

Что касается применения специальных средств, то статья 21 Федерального закона от 7 февраля 2011 г. № 3-Ф3 «О полиции» устанавливает как случаи, когда полицейский вправе применять специальные средства (например, для отражения нападения на гражданина или сотрудника полиции; для пресечения преступления или административного правонарушения; для задержания лица, если это лицо может оказать вооруженное сопротивление, и др.), так и перечень специальных средств (к ним, в частности, относятся: палки специальные, специальные газовые средства, средства ограничения подвижности, специальные окрашивающие и маркирующие средства, электрошоковые устройства, светошоковые устройства, служебные животные, бронемашины и др.), которые могут применяться в том или ином случае.

Сотрудник полиции не вправе применять специальные средства: в отношении женщин с видимыми признаками беременности, лиц с явными признаками инвалидности и малолетних лиц, за исключением случаев оказания указанными лицами вооруженного сопротивления, совершения группового либо иного нападения, угрожающего жизни и здоровью граждан или сотрудника полиции; при пресечении незаконных собраний, митингов, демонстраций, шествий и пикетирований ненасильственного характера, которые не нарушают общественный порядок, работу транспорта, средств связи и организаций (статья 22 Федерального закона от 7 февраля 2011 г. № 3-Ф3 «О полиции»). Кроме того, водометы не могут применяться, если температура воздуха ниже ноля градусов по шкале Цельсия. Не допускается также нанесение ударов человеку палкой специальной по голове, шее, ключичной области, животу, половым органам, в область проекции сердца.

Исчерпывающий перечень оснований применения огнестрельного оружия сотрудником полиции приведен в статье 23 Федерального закона от 7 февраля 2011 г. № 3-Ф3 «О полиции» (например, для защиты другого лица либо себя от посягательства, если это посягательство сопряжено с насилием, опасным для жизни или здоровья; для освобождения заложников и др.).

При попытке лица, задерживаемого сотрудником полиции с обнаженным огнестрельным оружием, приблизиться к сотруднику полиции, сократив при этом указанное им расстояние, или прикоснуться к его огнестрельному оружию сотрудник полиции вправе применить огнестрельное оружие.

Нельзя применять огнестрельное оружие в отношении женщин, лиц с явными признаками инвалидности, несовершеннолетних, когда их возраст очевиден, за исключением случаев оказания указанными лицами вооруженного сопротивления, совершения вооруженного или группового нападения, угрожающего жизни и здоровью людей или самого сотрудника полиции.

Также сотруднику полиции запрещается применение огнестрельного оружия при значительном скоплении граждан, если в результате его применения могут пострадать случайные лица.

Субъективный характер данного условия - если в результате его применения могут пострадать случайные лица - может создавать проблемы в применении этой нормы, поскольку неясно, как оценить степень вероятности причинения вреда случайным лицам.

Заслуживает поддержки предложение В.И. Ковшевацкого о необходимости дополнения пункта 1 статьи 27 Федерального закона «О полиции» обязанностью при выполнении служебных обязанностей, предполагающих возможность применения огнестрельного оружия, использовать штатные средства самозащиты (каски, щиты, пуленепробиваемые транспортные средства), что будет способствовать уверенности сотрудника полиции в собственной безопасности и его более уравновешенным и рациональным действиям [6]. 
Проведенный нами анализ некоторых аспектов реализации сотрудником полиции права на самозащиту при выполнении служебной деятельности показал, что специальные, «профессиональные» пределы реализации права сотрудника полиции на самозащиту связаны не с содержанием субъективного права на самозащиту, не с объемом правомочий этого субъективного права, а с особым порядком его реализации.

Кроме того, нами выявлены отдельные недостатки правового регулирования отношений в проанализированной сфере и предложены пути их устранения.

$$
* * *
$$

1. Послание Президента Российской Федерации Федеральному Собранию от 1 декабря 2016 г. // Парламентская газета. 2 - 8 декабря 2016 г. № 45.

2. Кустов П.В., Наумов И.П., Ткаченко А.Ю. Анализ применения приемов самозащиты работниками полиции при задержании правонарушителей // Современные тенденции развития науки и технологий. 2017. № 1-7. C. 78-80.

3. Собрание законодательства Российской Федерации. 2011. № 7. Ст. 900.

4. Орешкина Т.Ю. Система обязательств, исключающих преступность деяния // Lexrussica. 2015. № 3. С. $73-85$.

5. Определение Судебной коллегии по уголовным делам Верховного Суда Российской Федерации от 2 октября 2007 г. по делу № 56-007-53 // Справочная правовая система «Консультант Плюс». Информационный банк «Судебная практика».

6. Ковшевацкий В.И. Особенности применения физической силы, специальных средств и огнестрельного оружия сотрудниками полиции при оказании принудительной помощи гражданам // Вестник Московского университета МВД России. 2013. № 1. С. 139. 